\title{
A rapid spread of the Stony Coral Tissue Loss Disease outbreak in the Mexican Caribbean
}

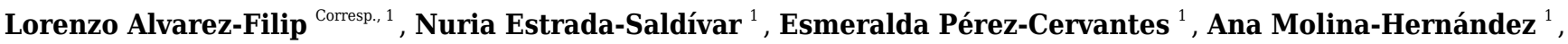 \\ Francisco J. Gonzalez-Barrios ${ }^{1}$ \\ 1 Biodiversity and Reef Conservation Laboratory, Unidad Académica de Sistemas Arrecifales, Instituto de Ciencias del Mar y Limnología, Universidad \\ Nacional Autónoma de México, Puerto Morelos, Quintana Roo, Mexico \\ Corresponding Author: Lorenzo Alvarez-Filip \\ Email address: Iorenzoaf@gmail.com
}

Caribbean reef corals have experienced unprecedented declines from climate change, anthropogenic stressors and infectious diseases in recent decades. Since 2014, a highly lethal, new disease, called stony coral tissue loss disease (SCTLD), has impacted many reef-coral species in Florida. During the summer of 2018, we noticed an anomalously high disease prevalence affecting different coral species in the northern portion of the Mexican Caribbean. We assessed the severity of this outbreak in 2018/2019 using the AGRRA coral protocol to survey 82 reef sites across the Mexican Caribbean. Then, using a subset of 14 sites, we detailed information from before the outbreak (2016/2017) to explore the consequences of the disease on the condition and composition of coral communities. Our findings show that the disease outbreak has already spread across the entire region by affecting similar species (with similar disease patterns) to those previously described for Florida. However, we observed a great variability in prevalence and tissue mortality that was not attributable to any geographical gradient. Using long-term data, we determined that there is no evidence of such high coral disease prevalence anywhere in the region before 2018, which suggests that the entire Mexican Caribbean was afflicted by the disease within a few months. The analysis of sites that contained pre-outbreak information showed that this event considerably increased coral mortality and severely changed the structure of coral communities in the region. Given the high prevalence and lethality of this disease, and the high number of susceptible species, we encourage reef researchers, managers and stakeholders across the Western Atlantic to accord it the highest priority for the near future. 


\section{A rapid spread of the Stony Coral Tissue Loss}

\section{Disease outbreak in the Mexican Caribbean}

3

4

Lorenzo Alvarez-Filip 1*, Nuria Estrada-Saldívar ${ }^{1}$, Esmeralda Pérez-Cervantes ${ }^{1}$, Ana L. Molina-Hernández ${ }^{1}$, Francisco J. González-Barrios ${ }^{1}$

${ }^{1}$ Biodiversity and Reef Conservation Laboratory, Unidad Académica de Sistemas Arrecifales, Instituto de Ciencias del Mar y Limnología, Universidad Nacional Autónoma de México, Puerto Morelos, Quintana Roo, México

Corresponding Author:

Lorenzo Alvarez-Filip ${ }^{1}$

Unidad Académica de Sistemas Arrecifales, Instituto de Ciencias del Mar y Limnología, Universidad Nacional Autónoma de México, Puerto Morelos, Quintana Roo, México Email address: lorenzo@cmarl.unam.mx

\section{Abstract}

Caribbean reef corals have experienced unprecedented declines from climate change, anthropogenic stressors and infectious diseases in recent decades. Since 2014, a highly lethal, new disease, called stony coral tissue loss disease (SCTLD), has impacted many reef-coral species in Florida. During the summer of 2018, we noticed an anomalously high disease prevalence affecting different coral species in the northern portion of the Mexican Caribbean. We assessed the severity of this outbreak in 2018/2019 using the AGRRA coral protocol to survey 82 reef sites across the Mexican Caribbean. Then, using a subset of 14 sites, we detailed information from before the outbreak (2016/2017) to explore the consequences of the disease on the condition and composition of coral communities. Our findings show that the disease outbreak has already spread across the entire region by affecting similar species (with similar disease patterns) to those previously described for Florida. However, we observed a great variability in prevalence and tissue mortality that was not attributable to any geographical gradient. Using long-term data, we determined that there is no evidence of such high coral disease prevalence anywhere in the region before 2018, which suggests that the entire Mexican Caribbean was afflicted by the disease within a few months. The analysis of sites that contained pre-outbreak information showed that this event considerably increased coral mortality and severely changed the structure of coral communities in the region. Given the high prevalence and lethality of this disease, and the high number of susceptible species, we encourage reef researchers, managers and stakeholders across the Western Atlantic to accord it the highest priority for the near future. 
39

40

41

42

43

44

45

46

47

48

49

50

51

52

53

54

55

56

57

58

59

60

61

62

63

64

65

66

67

68

69

70

71

72

73

74

75

76

77

78

Keywords: White plague; White syndrome; SCTLD; Coral mortality; Disease prevalence; Reef monitoring; Long-term data, Reef functioning

Note: This manuscript is meant for inclusion in the proceedings of the 39th meeting of the Association of Marine Laboratories of the Caribbean (AMLC).

\section{Introduction}

Over the past four decades, coral reefs have experienced declines in their condition and function, which has been attributed to coral disease, overfishing and herbivore loss, eutrophication, sedimentation, and climate change (Jackson et al., 2014; Hughes et al., 2017; Lapointe et al., 2019). For the Caribbean in particular, diseases have caused devastating declines in living coral cover of more than $50 \%$ to $80 \%$ within a few decades (Aronson \& Precht, 2001; Jackson et al., 2014). Furthermore, diseases have also impacted populations of other key components of Caribbean ecosystems, such as the decimation of Diadema antillarum populations due to a nonidentified pathogen during the 1980s (Lessios et al., 1984). The region-wide outbreak of the white-band disease in the late 1970s led to a substantial loss of the major reef-building corals Acropora palmata and Acropora cervicornis (Gladfelter, 1982; Aronson \& Precht, 2001). It is estimated that nearly $80 \%$ of the population was lost during this event (Gladfelter, 1982; Aronson \& Precht, 1997). In the late 1990s, the white-pox disease, apparently caused by a human-related pathogen, further decimated the populations of A. palmata (Patterson et al., 2002). In addition, the increase in the incidence of the yellow-band disease during the 1990s affected the populations of Orbicella spp., which are important reef-building species that tend to dominate many fore-reef zones (Cervino et al., 2001; Gil-Agudelo et al., 2004). Multiple events of white-plague disease outbreaks during the last decades have also substantially decimated the populations of a range of coral species (Weil, 2004; Harvell, 2007; Precht et al., 2016). It has been suggested for some sites that white-plague disease may have a greater impact on the Caribbean than other diseases (Cróquer et al., 2005). Due to the fact that the most severely impacted coral species are also major reef-building corals, disease outbreaks in the Caribbean have largely contributed to the substantial changes in spatial heterogeneity and ecological functionality of Caribbean reefs, along with their capacity to provide important ecosystem services to humans (Alvarez-Filip et al., 2009; Aronson \& Precht, 2001; Weil, 2004).

Although Caribbean reef-related diseases were first reported in the early 1970s, our knowledge of their pathology, etiology, and epizootiology (i.e. what are the main drivers that potentially trigger a disease outbreaks) of most coral reef diseases is still limited. However, it is likely that increasing pressures in the form of climate change and coastal development will increase disease prevalence and the negative effects of diseases on coral communities. For instance, coral diseases are likely to be exacerbated in a context of rapidly increasing sea surface temperatures, as thermal stress has been linked to coral disease outbreaks (Bruno et al., 2007; Randall et al., 
82

83

84

85

86

87

88

89

90

91

92

93

94

95

96

97

98

99

100

101

102

103

104

105

106

107

108

109

110

111

112

113

114

115

116

117

118

2014; van Woesik \& McCaffrey 2017). In addition, coral diseases have also been related to stressors such as excess nutrients from sewage or high levels of sedimentation (e.g. Sutherland et al., 2010, Bruno et al., 2003).

In 2014, a new emergent coral disease, the Stony Coral Tissue Loss Disease (SCTLD), was first reported off the coast of Miami-Dade County, Florida in September 2014, just after an intense bleaching event during the summer of the same year (Precht et al., 2016; Precht, 2019; FDEP, 2019). Since then, the SCTLD has gradually spread across the Florida Reef Tract (FDEP, 2019) and began to reach other regions in the Caribbean (AGRRA, 2019). In Florida, regional declines in coral density approached $30 \%$ loss and live tissue loss was upward of $60 \%$ as a result of the disease outbreak (Walton et al., 2018). The cause of the disease is still unknown but it is affecting more than 20 species of corals (FDEP, 2019), with highly-susceptible species showing initial signs of infection, followed by intermediate-susceptible species (FDEP, 2019). The most evident symptom is the display of multiple lesions that provoke rapid tissue loss, leading to the exposure of bright white skeletons that are rapidly covered by turf, macroalgae or sediment. Highly susceptible species include Pseudodiploria strigosa, Dendrogyra cylindrus, Meandrina meandrites, Dichocoenia stokesii, Montastraea cavernosa and Eusmilia fastigiata, among others (Precht et al. 2016; Precht, 2019; FDEP, 2019). According to early reports, the SCTLD has not shown seasonal patterns linked to warming or cooling ocean temperatures, contrary to previous white plague diseases that have subsided in winter months as temperatures cooled (Harding et al 2008; Miller et al 2009; FDEP, 2019).

On July 2018, following alerting reports issued by local divers, and in collaboration with the authorities of the Parque Nacional Arrecife de Puerto Morelos, we found a reef near Puerto Morelos, in the northern Mexican Caribbean that had a severe outbreak of a coral disease affecting similar species and exhibiting similar patterns as those previously reported in Florida (Fig. 1). Since then, we set out to survey other reefs in the Mexican Caribbean and found that the disease outbreak spread quickly across the region. Here we document the impact of the SCTLD on coral communities in the Mexican Caribbean by (i) quantifying the disease prevalence at 82 sites, and (ii) describing how this disease has modified the condition and composition of coral communities at 14 sites by using detailed information from before the onset of the outbreak.

\section{Materials \& Methods}

Data for this region-wide assessment was produced by the Healthy Reefs Initiative (HRI), the Comisión Nacional de Áreas Naturales Protegidas (Mexican Commission for Protected Areas; CONANP) and the Biodiversity and Reef Conservation Laboratory, UNAM. Sites were defined according to ongoing monitoring programs and research projects, therefore it was not possible to design a survey protocol to systematically represent reef gradients or zonation. A total of 82 sites were surveyed over the period July 2018 - April 2019 (Table S1). Seventy-seven sites are fore- 
119 reefs (7-15 $\mathrm{m}$ deep) and five are back-reefs (1-3 $\mathrm{m}$ deep). All sites were surveyed using the 120 AGRRA coral protocol (Lang et al. 2012).

121

122

123

124

125

126

127

128

129

130

131

132

133

134

135

136

137

138

139

140

141

142

143

144

145

146

147

148

149

150

151

152

153

154

155

156

157

158

At each site, coral communities were surveyed by replicating 2 to $16($ mean $=4.3 ; \mathrm{SD}=3.7)$ belt transects of 10x1 m (Table S1). Although two transects is the minimum recommended by the AGRRA coral protocol (Lang et al. 2012), we aimed for more transects when possible in order to have a better representation of the coral community and disease prevalence. The following data were recorded for each coral colony within the transect: species name, colony size (maximum diameter, diameter perpendicular to the maximum and height), percentage of bleaching, percentage of mortality (new, transition and old) and the presence of SCTLD and other diseases (Lang et al., 2012). We then calculated the SCTLD prevalence at each site and for all coral species. For this study, we also recorded colonies with $100 \%$ mortality for which death could be attributable to the SCTLD (i.e., recent or transient mortality was still evident; see Fig. 1). To provide a clearer picture of the magnitude of the problem, we focused on exploring geographical and temporal trends for the 11 most 'highly susceptible species', which we defined as those that presented more than $10 \%$ of SCTLD prevalence across all surveyed sites (Fig. 2; Table S2).

To identify whether the SCTLD outbreak may have started earlier than the summer of 2018, a variety of published and unpublished sources were used to provide a yearly estimate of disease prevalence at a regional level. Datasets were obtained from AGRRA, the HRI, CONANP monitoring protocols and scientific sources (publications and researchers), and are being systematized in the Coral Reef Information System of the Biodiversity and Reef Conservation Laboratory, UNAM (Table S1). Since the main intention of this exercise was to provide a regional perspective of disease prevalence, we only used years for which enough geographical representation exists. In other words, we included years with information from at least 17 sites distributed in at least three of the main sub-regions identified for the Mexican Caribbean (Northern Quintana Roo, Central Quintana Roo, Southern Quintana Roo, Cozumel and Chinchorro Bank; Rioja-Nieto \& Álvarez-Filip, 2019). In total, we present data for 7 time periods: 2005/2006, 2009, 2011/2012, 2014, 2016, 2017, and 2018/2019. Some years were combined into one period, as they were part of the same monitoring campaign (i.e. sites were surveyed only once within each period).

In 2016 and 2017 we conducted an extensive effort to survey coral reefs systems across the Mexican Caribbean (e.g. Suchley \& Alvarez-Filip, 2018; Perry et al., 2018). Although surveying the condition of coral communities was not part of the objectives of those campaigns, we assessed coral communities in 14 of those sites using the AGRRA methodology (see above). In 2018 and 2019 we revisited these 14 sites to compare how coral condition and coral community composition changed from before the SCTLD outbreak to after the onset of the outbreak (in 2018/2019). These sites are distributed in the northern portion of the Mexican Caribbean: from Punta Allen to Puerto Morelos in the mainland, and in the windward and leeward coasts of

PeerJ reviewing PDF | (2019:07:39899:1:1:NEW 17 Oct 2019) 
159 Cozumel (Fig. 3). Eleven sites are fore reefs and three are back-reefs. To describe patterns of 160 coral mortality between periods, we first calculated the proportion of healthy, afflicted and dead 161 colonies for each period (2016/2017 and 2018/2019). As described above, for this analysis we

162

163

164

165

166

167

168

169

170

171

172

173

174

175

176

177

178

179

180

181

182

183

184

185

186

187

188

189

190

191

192

193

194

195

196

197

198

only considered the 11 most 'highly susceptible species'.

The variation in the overall coral community composition (including all recorded species) between 2016/2017 and 2018/2019 was investigated with non-metric multidimensional scaling (nMDS) based on Bray-Curtis similarities of square root transformed coral cover species data in Primer v6 (Clarke \& Gorley., 2006). The matrix was created using the relative abundance of each healthy, afflicted, and dead colony for each coral species for each period. The relative abundance of each coral species was used as the variable, the sites as the samples. We used the before and after periods, and the reef zones as factors. A two-way Analysis of Similarities (ANOSIM) was used to test the significance of these groupings (9999 permutations).

We then used the convex hull (polygon delineated by the exterior points of each period in the nMDS) to represent the variability of the coral community for each time period (2016-2017 vs 2018-2019), and the standard ellipse area (SEA) to quantitatively explore the overlap between the two periods. Briefly, the standard ellipse is to bivariate data as standard deviation is to univariate data. The standard ellipse of a set of bivariate data is calculated from the variance and covariance of the two axes and contains approximately $40 \%$ of the data (Jackson et al., 2012). To compare the total area for each time period, we used the Bayesian standard ellipse area corrected for the sample size (SEAc) estimated, and plotted it using the SIBER routine for the SIAR package in $\mathrm{R}$ (Parnell et al., 2015). The overlap of the time period was calculated as the overlapping proportion of the SEAc (Jackson et al., 2011).

\section{Results \& Discussion}

Here we describe how the SCTLD affected 82 reef sites distributed along the Mexican Caribbean coast. More than $40 \%$ of the sites had a SCTLD prevalence of $10 \%$ or more, and nearly a quarter of the sites had a disease prevalence of more than $30 \%$ (Fig. 3). Our results should be taken as a conservative value, since many sites were surveyed when the SCTLD outbreak was only starting (i.e., only a few colonies of a few species were afflicted by the disease; Fig. 3). We observed great variability in prevalence that was not attributable to any geographical gradient or seasonality (Fig. 3). For example, the SCTLD was first observed in Cozumel's windward coast in November 2018 (as in most of the surveyed sites in the mainland); however, it was not until December 2018 that the disease reached the reefs in the leeward side of Cozumel, followed by rapid spreading during the winter. Overall, the presence of the SCTLD in the Mexican Caribbean during 2018/2019 was well above the 5\% disease prevalence, that has been identified as habitual for Caribbean reefs (Weil, 2004; Ruiz-Moreno et al., 2012), and just slightly lower than what has been reported for Florida a few years after the start of the SCTLD outbreak (Walton et al., 2018).

PeerJ reviewing PDF | (2019:07:39899:1:1:NEW 17 Oct 2019) 
199 During the past 13 years, disease prevalence in the Mexican Caribbean was below 10\%, and it 200 reached its lowest point during 2016-2017, just one year before the SCTLD outbreak in this 201 region, with only 1\% prevalence (Fig. 4). Similarly throughout the Florida Reef Tract, the 202 prevalence of disease before the first SCTLD reports was below 2\%, but this prevalence doubled 203 after the region-wide outbreak (Walton et al., 2018). For this study, we present the temporal 204 trend of disease prevalence to provide context to the SCTLD outbreak. However, we

205

206

207

208

209

210

211

212

213

214

215

216

217

218

219

220

221

222

223

224

225

226

227

228

229

230

231

232

233

234

235

236

237 acknowledge that the information presented in Fig. 4 should be taken conservatively, since prevalence values are usually driven by few (sometimes different) afflicted species and are dependent on coral mortality from previous years.

For Florida, it has been shown that the 2014 SCTLD disease outbreak was linked to a severe thermal stress resulting from warm winter and spring temperatures followed by an anomalously warm summer (Gintert et al., 2019; van Woesik \& McCaffrey, 2017; Walton et al., 2018). For the Mexican Caribbean, we did not find evidence of intense thermal stress during this study (July 2018 - April 2019). Coral bleaching was very low and unrelated to the disease prevalence in all our surveyed sites (Fig. S1). However, and although sea-surface temperatures rarely exceeded the bleaching threshold, temperature anomalies during the winter were relatively high (CerdeiraEstrada et al., 2019; Fig. S1). The above-normal temperatures during the winter might have contributed to the rapid spread of the disease observed in Cozumel's leeward coast during this season, since coral diseases are likely to be exacerbated by thermal stress (Bruno et al., 2007; Randall et al., 2014; van Woesik \& McCaffrey 2017). During this study, there were no other severe natural events, such as tropical storms or extraordinary rainfall that affected our study sites.

The SCTLD has a very high host range Our field surveys revealed that 24 out of 46 recorded species presented symptoms of SCTLD with a high disease prevalence: Dendrogyra cylindrus (71\%, 5 out of 7 colonies), Pseudodiploria strigosa (40\%), Meandrina meandrites (38\%), Eusmilia fastigiata (33\%), Siderastrea siderea (26\%), Diploria labyrinthiformis (25\%), among others (Fig. 2, Table S2). As in Florida, we have also observed that some of the most susceptible species have disappeared from long-term monitoring sites. Potentially, this emergent disease has even driven local-extinction events of species such as M. meandrites and D. cylindrus, since these species that have vanished from several reef sites on the mainland coast of our study region. In fact, a recent study suggests that $D$. cylindrus, a species that has been rare for hundreds of thousands of years, has a high likelihood of becoming extinct in the coming years due to this disease outbreak (Chan et al., 2019). We still recorded healthy colonies of M. meandrites and $D$. cylindrus at Chinchorro Bank and Cozumel Island, but some of the more recent surveys (not included in this study) revealed that the colonies from these two species are increasingly being afflicted by the SCTLD in Cozumel. Although there is the precedent of other diseases affecting multiple species in the Caribbean, such as the black band disease, yellow band syndrome and White Plague type II (Weil, 2004), it is possible that the SCTLD may become one of most lethal 
238

239

240

241

242

243

244

245

246

247

248

249

250

251

252

253

254

255

256

257

258

259

260

261

262

263

264

265

266

267

268

269

270

271

272

273

274

275

276

diseases in the recent history of the region, given the high levels of prevalence and high mortality rates on several coral species (see also FDEP, 2019; Gintert et al., 2019).

Although there are some differences between the lists (and ranking) of afflicted species identified for the Mexican Caribbean (this study) and those reported for Florida (e.g. Precht et al., 2016 and Walton et al., 2018), the overall pattern is similar. Many of the species that remained as important reef-building corals after the declines of Acropora and Orbicella, are being severely affected by the SCTLD (Gonzalez-Barrios \& Alvarez-Filip, 2018; Fig. 2). Complexity-contributing species that exhibited significant declines include $P$. strigosa, $D$. labyrinthiformis, C. natans and M. cavernosa (Fig. 2). In contrast, we found very low disease prevalence on non-framework building corals such as Agaricia agaricites and Porites astreoides, which are species that have been previously described as intermediately-susceptible species to the SCTLD (FDEP, 2019). These two species are very abundant across reef sites in the Mexican Caribbean and the wider Caribbean (Table S1; Green, Edmunds \& Carpenter, 2008; GonzalezBarrios \& Alvarez-Filip, 2018). Therefore, the decline in the abundance of several species due to the SCTLD is likely to further increase the dominance of $A$. agaricites and P. astreoides in the region. This may have started to become apparent already. The relative abundance of these two species represented $46 \%$ of the surveyed colonies in 2016 and 2017, yet by 2018/2019 they accounted for $52 \%$ of the total number of recorded coral colonies. However, this is a preliminary observation and further studies should assess coral communities once the SCTLD has already passed its peak in the region. Overall, these findings suggest that the ultimate consequence of the SCTLD outbreak may be a further decrease on the physical persistence and ecological functionality of coral reefs (Alvarez-Filip et al., 2013; Perry et al., 2015; Perry \& Alvarez-Filip, 2019).

Transmission, or the spread of disease among individuals, is a key factor in understanding the epidemiology and ecology of infectious diseases (Shore \& Caldwell, 2019). Although the data for this study was not collected in a way that allowed us to quantitatively explore how the disease is transmitted between colonies, it is important to mention that we did not observe evidence that suggests a single potential mechanism of disease transmission. For example, we repeatedly observed, at different sites, individuals of the butterflyfish Chaetodon capistratus feeding on the edge of the lesions and then swimming away to feed off on other (healthy or afflicted) colonies (Fig 1A). This behavior of C. capistratus was commonly observed on colonies of $P$. strigosa but very occasionally on other susceptible species such as $D$.

labyrinthiformis and Orbicella spp. During our field surveys it was also common to observe that neighboring colonies were afflicted (e.g. Fig. 1A), but in other instances we found colonies of the same species in direct contact with each other with no evidence of transmission from the afflicted colony to the apparently healthy colony (e.g. Fig 1B). Thus, although it is suspected that the SCTLD is infectious (transmissible from a sick coral to a healthy coral), further pathological, 
277 etiological and genetic analyses are required to fully understand the sources and mechanisms of 278 transmission of this emergent threat to Caribbean reefs.

279

280

281

282

283

284

285

286

287

288

289

290

291

292

293

294

295

296

297

298

299

300

301

302

303

304

305

306

307

308

309

310

311

312

313

314

315

316

The analysis of sites that contained pre-outbreak information showed that this outbreak event considerably increased coral mortality and severely changed the structure of coral communities in the region. In total, we surveyed 3,059 coral colonies of the highly susceptible species for both periods (2016/2017 and 2018/2019). During the pre-outbreak period, $99.5 \%$ of the coral colonies were healthy, yet during 2018-2019 the disease prevalence reached $25.9 \%$, while another $12.9 \%$ of the colonies were already dead; probably as a consequence of the SCTLD (Fig. 5). All the colonies exhibited similar symptoms to those colonies from Florida, with rapid tissue loss occurring within a period of just a few weeks in the most extreme cases, leaving the white skeletons exposed, which were either colonized by macroalgae or covered by sediment shortly after. Additionally, our percentage of afflicted colonies by the SCTLD is similar to what was observed in Florida during 2014-2015, where they registered a 30\% proportion of afflicted colonies (Precht et al., 2016). The coral community composition of those 14 sites changed considerably between the pre-outbreak surveys and 2018/2019 (Fig. 6). The two-way ANOSIM showed significant differences between sampling periods $(\mathrm{R}=0.561, \mathrm{p}=$ $0.001)$ and reef zones $(\mathrm{R}=0.44, \mathrm{p}=0.004)$. The analysis revealed that the period of 2018/2019 had no overlap with the period of 2017/2019, which means that this corresponds to compositional changes in the coral reef communities. This is particularly explained by the sudden increase of afflicted colonies and of the number of dead colonies, especially from the species M. meandrites, P. strigosa, D. labyrinthiformis and E. fastigiata. This massive diseaseoutbreak is a clear example of how coral diseases are drivers of change for coral communities (Harvell et al., 2007).

The SCTLD outbreak reached the north of the Mesoamerican Reef System in 2018, which affected most of the coral reefs throughout the 400 linear $\mathrm{km}$ of the Mexican Caribbean coast in less than a year with a non-recognizable geographical pattern. This pattern contrasts the gradual spread observed across the Florida Reef Tract between 2014 and 2019 (FDEP, 2019). The extremely rapid geographical progression of the SCTLD across the Mexican Caribbean could be explained, at least in part, by the rapidly decreasing quality of sea water in the region. The Mexican Caribbean coast has experienced dramatic coastal development over the last decades. Over 10 million tourists visit the region annually and the local population has grown exponentially (Suchley \& Alvarez-Filip, 2018). Consequently, the coastal waters of the region have experienced eutrophication and increased sedimentation levels (Murray, 2007; Baker et al., 2013; Hernández-Terrones et al., 2015). Eutrophication resulting from inadequate wastewater treatment has been previously identified as a major driver of declining reef condition in the region (e.g. Suchley \& Alvarez-Filip, 2018). In addition and more recently, the Mexican Caribbean coast has regularly experienced a massive influx of drifting Sargassum that accumulates on the shores and rapidly decomposes, resulting in near-shore, murky-brown waters

PeerJ reviewing PDF | (2019:07:39899:1:1:NEW 17 Oct 2019) 
317 that rapidly increases nutrient concentration in the water column and reduces light, oxygen and

318

319

320

321

322

323

324

325

326

327

328

329

330

331

332

333

334

335

336

337

338

339

340

341

342

343

344

345

346

347

348

349

350

351

352

353

354

355

356

pH levels (van Tussenbroek et al., 2017). These sargassum-brown-tides have been proven to have drastic consequences on near-shore seagrass meadows and coral communities (van Tussenbroek et al., 2017). Given the large amount of Sargassum reaching the coast, these negative effects are likely to disseminate further offshore reaching coral reefs (usually located 0.5-3 km from the coast). Further research is needed to fully comprehend the relationship between rapidly changing water quality in the Mexican Caribbean and the susceptibility of reef corals to diseases; however, chronic nutrient enrichment has already been related to coral diseases and bleaching under experimental conditions (Vega Thurber et al., 2013).

\section{Conclusion}

The Caribbean region is a well-known 'disease hot-spot' because of the fast emergence, high prevalence, and virulence of coral-reef diseases and syndromes (Weil, 2004). These events have deeply marked the community composition of Caribbean reefs by decimating populations of important reef-building coral species such as A. palmata, which has not fully recovered from these events (e.g. Rodríguez-Martínez et al., 2014). However, the SCTLD is likely to become the most lethal coral disease ever recorded because of its high prevalence, the high number of susceptible species, its transmissibility, and the high levels of mortality exhibited by affected corals (Precht et al., 2016; Precht et al., 2018; Gintert et al., 2019). A total of 29 species, including rare and important reef-building coral species, have been reported to be affected by the SCTLD (this study; Precht et al., 2016; Walton et al., 2018; FDEP, 2019), but even more concerning is the fact that this disease is covering a wide geographic range and it is expanding rapidly. Recent, reports of the SCTLD have also been issued for Jamaica, St. Maarten, the Dominican Republic and St. Thomas in the U.S. Virgin Islands (AGRRA, 2019). The ultimate consequences for the wider Caribbean are yet to be seen, however, our findings suggest that this event has the potential to further decrease physical persistence and ecological functionality of coral reefs at a regional scale (Perry \& Alvarez-Filip 2019). Amelioration or eradication intervention have only partially succeeded in impeding the spread of the SCTLD disease across Florida and Mexico, in part because the disease is spreading more rapidly (weeks) than our capacity (scientists, managers, stakeholders) to respond to these types of events (e.g. Precht, 2019). Given the high prevalence and lethality of this disease, and the high number of susceptible species, we encourage reef researchers, managers and stakeholders across the Caribbean to accord it the highest priority for the near future.

\section{Acknowledgements}

We are grateful to Melina Soto, Maria del Carmen García, Alba González-Posada, Eduardo Navarro, Francisco Medellín, Blanca Quiroga, Ernesto Hevia, Eric Jordan, Nallely Hernández, Cristopher Gonzalez, Claudia Padilla, and Judith Lang who collected part of the data and/or

PeerJ reviewing PDF | (2019:07:39899:1:1:NEW 17 Oct 2019) 
357

358

359

360

361

362

363

364

365

366

367

368

369

370

371

372

373

374

375

376

377

378

379

380

381

382

383

384

385

386

387

388

389

390

391

392

provided insightful discussions that significantly improved the manuscript. Data from the longterm monitoring programs of the Healthy Reefs Initiative, Parque Nacional Arrecifes de Cozumel and Parque Nacional Arrecife de Puerto Morelos were essential to provide the historical background to this disease outbreak. The Comisión Nacional de Áreas Protegidas is currently coordinating the Disease Response Plan for the Mexican Caribbean, this initiative allowed us to present and discuss with a broader group of scientists, managers and NGOs our preliminary observations. The Atlantic and Gulf Rapid Reef Assessment program provided support to L.A.-F. to attend and present an earlier version of this study in the 39th meeting of the Association of Marine Laboratories of the Caribbean in Punta Cana, Dominican Republic. We thank Victor Rodríguez Ruano for their valuable time proofreading the manuscript.

\section{References}

AGRRA 2019. Coral Disease Outbreak, Stony coral tissue loss disease http:/www.agrra.org/coral-disease-outbreak/

Alvarez-Filip L, Carricart-Ganivet JP, Horta-Puga G, Iglesias-Prieto R. 2013. Shifts in coralassemblage composition do not ensure persistence of reef functionality. Scientific Reports. DOI: $10.1038 /$ srep03486.

Alvarez-Filip L, Dulvy NK, Gill JA, Côté IM, Watkinson AR. 2009. Flattening of Caribbean coral reefs: Region-wide declines in architectural complexity. Proceedings of the Royal Society B: Biological Sciences 276:3019-3025. DOI: 10.1098/rspb.2009.0339.

Aronson RB, Precht WF. 2001. White-band disease and the changing face of Caribbean coral reefs. In: Porter JW ed. The Ecology and Etiology of Newly Emerging Marine Diseases. Dordrecht: Springer Netherlands, 25-38. DOI: 10.1007/978-94-017-3284-0_2.

Aronson RB, Precht WF. 1997. Stasis, biological disturbance, and community structure of a Holocene coral reef. Paleobiology 23:326-346. DOI: 10.1017/S0094837300019710.

Baker DM, Rodríguez-Martínez RE, Fogel ML. 2013. Tourism's nitrogen footprint on a Mesoamerican coral reef. Coral Reefs. DOI: 10.1007/s00338-013-1040-2.

Bruno JF, Petes LE, Harvell CD, Hettinger A. 2003. Nutrient enrichment can increase the severity of coral diseases. Ecology Letters. DOI: 10.1046/j.1461-0248.2003.00544.x.

Bruno JF, Selig ER, Casey KS, Page CA, Willis BL, Harvell CD, Sweatman H, Melendy AM. 2007. Thermal stress and coral cover as drivers of coral disease outbreaks. PLoS Biology. DOI: $10.1371 /$ journal.pbio.0050124.

Cerdeira-Estrada, S., R. Martell-Dubois, J. Valdéz, R. Ressl. 2019. Monthly night time Sea Surface Temperature (M-NSST) at 1-km. Satellite-based ocean monitoring system (SATMO). Marine-Coastal Information and Analysis System (SIMAR). CONABIO. México. Dataset accessed [2018-05-10] at simar.conabio.gob.mx. 
393

394

395

396

397

398

399

400

401

402

403

404

405

406

407

408

409

410

411

412

413

414

415

416

417

418

419

420

421

422

423

424

425

Cervino, J., Goreau, T. J., Nagelkerken, I., Smith, G. W., \& Hayes, R. 2001. Yellow band and dark spot syndromes in Caribbean corals: distribution, rate of spread, cytology, and effects on abundance and division rate of zooxanthellae. In: The Ecology and Etiology of Newly Emerging Marine Diseases.

Chan AN, Lewis CL, Neely KL, Baums IB. 2019. Fallen Pillars: The past, present, and future population dynamics of a rare, specialist coral-algal symbiosis. Frontiers in Marine Science 6:1-18. DOI: 10.3389/fmars.2019.00218.

Clarke KR, Gorley RN. 2006. PRIMER v6:

Cróquer A, Weil E, Zubillaga AL, Pauls SM. 2005. Impact of a white plague-II outbreak on a coral reef in the archipelago Los Roques National Park, Venezuela. Caribbean Journal of Science.

FDEP (Florida Department Environmental Protection), 2019. Florida Reef Tract Coral Disease Outbreak (2014 - Present). https://floridadep.gov/fco/coral/content/florida-reef-tract-coraldisease-outbreak

Gil-Agudelo DL, Smith GW, Garzón-Ferreira J, Weil E, Petersen D. 2004. Dark Spots Disease and Yellow Band Disease, Two Poorly Known Coral Diseases with High Incidence in Caribbean Reefs. In: Coral Health and Disease. DOI: 10.1007/978-3-662-06414-6_19.

Gladfelter WB. 1982. White-band disease in Acropora palmata: implications for the structure and growth of shallow reefs. Bull Mar Sci.

Gintert BE, Precht WF, Fura R, Rogers K, Rice M, Precht LL, D’Alessandro M, Croop J, Vilmar C, Robbart ML. 2019. Regional coral disease outbreak overwhelms impacts from local dredge project. Environmental Monitoring and Assessment 191

González-Barrios FJ, Álvarez-Filip L. 2018. A framework for measuring coral species-specific contribution to reef functioning in the Caribbean. Ecological Indicators 95:877-886. DOI: 10.1016/j.ecolind.2018.08.038.

Harding S, van Bochove JW, Day O, Gibson K, Raines P. 2008. Continued degradation of Tobago's coral reefs linked to the prevalence of coral disease following the 2005 mass coral bleaching event. Proceedings of the 11th International Coral reef symposium:738-741.

Harvell D, Jordán-Dahlgren E, Merkel S, Rosenberg E, Raymundo L, Smith G, Weil E, Willis B. 2007. Coral Disease, Environmental Drivers, and the Balance Between Coral and Microbial Associates. Oceanography. DOI: 10.5670/oceanog.2007.91.

Hernández-Terrones LM, Null KA, Ortega-Camacho D, Paytan A. 2015. Water quality assessment in the Mexican Caribbean : Impacts on the coastal ecosystem. Continental Shelf 
427

428

429

430

431

432

433

434

435

436

437

438

439

440

441

442

443

444

445

446

447

448

449

450

451

452

453

454

455

456

457

Hughes TP, Barnes ML, Bellwood DR, Cinner JE, Cumming GS, Jackson JBC, Kleypas J, Van De Leemput IA, Lough JM, Morrison TH, Palumbi SR, Van Nes EH, Scheffer M. 2017. Coral reefs in the Anthropocene. Nature 546:82-90. DOI: 10.1038/nature22901.

Jackson MC, Donohue I, Jackson AL, Britton JR, Harper DM, Grey J. 2012. Population-level metrics of trophic structure based on stable isotopes and their application to invasion ecology. PLoS ONE. DOI: 10.1371/journal.pone.0031757.

Jackson AL, Inger R, Parnell AC, Bearhop S. 2011. Comparing isotopic niche widths among and within communities: SIBER - Stable Isotope Bayesian Ellipses in R. Journal of Animal Ecology 80:595-602. DOI: 10.1111/j.1365-2656.2011.01806.x.

Jackson JBC, Donovan MK, Cramer KL LV. 2014. 1891-Status and Trends of Caribbean Coral Reefs- 1970-2012-2014 Caribbean Coral Reefs - Status Report 1970-2012 (1). Global Coral Reef Monitoring Network, IUCN, Gland, Switzerland.

Lang JC, Marks KW, Kramer PR, Kramer PA. 2012. Protocolos AGRRA 5.5. :1-44.

Lapointe, B.E., Brewton, R.A., Herren, L.W., Porter, J.W., Hu, C., 2019. Nitrogen enrichment, altered stoichiometry, and coral reef decline at Looe Key, Florida Keys, USA: a 3-decade study. Marine Biology, 166(8), 108

Lessios HA, Robertson DR, Cubit JD. 1984. Spread of Diadema mass mortality through the Caribbean. Science 226:335-337. DOI: 10.1126/science.226.4672.335.

Miller J, Muller E, Rogers C, Waara R, Atkinson A, Whelan KRT, Patterson M, Witcher B. 2009. Coral disease following massive bleaching in 2005 causes $60 \%$ decline in coral cover on reefs in the US Virgin Islands. Coral Reefs 28:925-937. DOI: 10.1007/s00338-0090531-7.Murray G. 2007. Constructing paradise: The impacts of big tourism in the Mexican coastal zone. Coastal Management. DOI: 10.1080/08920750601169600.

Parnell A, Jackson A. 2015. Package 'siar': Stable Isotope Analysis in R. R Found. Stat. Comput., Vienna:34. DOI: 10.1063/1.4919278.

Patterson KL, Porter JW, Ritchie KB, Polson SW, Mueller E, Peters EC, Santavy DL, Smith GW. 2002. The etiology of white pox, a lethal disease of the Caribbean elkhorn coral, Acropora palmata. Proceedings of the National Academy of Sciences. DOI: 10.1073/pnas.092260099.

Perry CT, Steneck RS, Murphy GN, Kench PS, Edinger EN, Smithers SG, Mumby PJ. 2015. Regional-scale dominance of non-framework building corals on Caribbean reefs affects 
458

459

460

461

462

463

464

465

466

467

468

469

470

471

472

473

474

475

476

477

478

479

480

481

482

483

484

485

486

487

488

489

490

491

carbonate production and future reef growth. Global Change Biology. DOI:

$10.1111 /$ gcb.12792.

Perry CT, Alvarez-Filip L, Graham NAJ, Mumby PJ, Wilson SK, Kench PS, Manzello DP, Morgan KM, Slangen ABA, Thomson DP, Januchowski-Hartley F, Smithers SG, Steneck RS, Carlton R, Edinger EN, Enochs IC, Estrada-Saldívar N, Haywood MDE, Kolodziej G, Murphy GN, Pérez-Cervantes E, Suchley A, Valentino L, Boenish R, Wilson M, MacDonald C. 2018. Loss of coral reef growth capacity to track future increases in sea level. Nature 558:396-400. DOI: 10.1038/s41586-018-0194-z.

Perry CT, Alvarez-Filip L. 2019. Changing geo-ecological functions of coral reefs in the Anthropocene. Functional Ecology. DOI: 10.1111/1365-2435.13247.Precht WF, Gintert BE, Robbart ML, Fura R, Van Woesik R. 2016. Unprecedented Disease-Related Coral Mortality in Southeastern Florida. Scientific Reports. DOI: 10.1038/srep31374.

Precht WF, Gintert BE, Robbart ML, Fura R, van Woesik R. 2016. Unprecedented DiseaseRelated Coral Mortality in Southeastern Florida. Scientific Reports 6:1-11. DOI: $10.1038 /$ srep31374.

Precht, W., Gintert,B., Fura, R., Precht, W.,Rogers,K., \& Robbart, M. (2018). Coral disease ravages reef-building corals throughout Southeast Florida. Inside Ecology (April 5, 2018) https://insideecology.com/2018/04/05/coral-disease-ravages- reef-building-coralsthroughoutsoutheast-florida/.

Precht WF. 2019. Failure to respond to a coral disease outbreak: Potential costs and consequences. PeerJ Preprints 7:e27860v2 https://doi.org/10.7287/peerj.preprints.27860v2

Randall CJ, Jordan-Garza AG, Muller EM, Van Woesik R. 2014. Relationships between the history of thermal stress and the relative risk of diseases of Caribbean corals. Ecology. DOI: 10.1890/13-0774.1.

Rioja-Nieto R, Álvarez-Filip L. 2019. Coral reef systems of the Mexican Caribbean: Status, recent trends and conservation. Marine Pollution Bulletin. DOI: 10.1016/j.marpolbul.2018.07.005.

Rodríguez-Martínez RE, Banaszak AT, McField MD, Beltrán-Torres AU, Álvarez-Filip L. 2014. Assessment of Acropora palmata in the mesoamerican reef system. PLoS ONE. DOI: 10.1371/journal.pone.0096140.

Ruiz-Moreno D, Willis BL, Page AC, Weil E, Cróquer A, Vargas-Angel B, Jordan-Garza AG, Jordán-Dahlgren E, Raymundo L, Harvell CD. 2012. Global coral disease prevalence associated with sea temperature anomalies and local factors. Diseases of Aquatic Organisms. DOI: 10.3354/dao02488. 
492 Shore A, Caldwell JM. 2019. Modes of coral disease transmission: how do diseases spread

493

494

495

496

497

498

499

500

501

502

503

504

505

506

507

508

509

510

511

512

513

514

515

516

517

518

519

520

521

522

523

524

525

526 between individuals and among populations? Marine Biology 166:1-14. DOI: 10.1007/s00227-019-3490-8.

Suchley A, Alvarez-Filip L. 2018. Local human activities limit marine protection efficacy on Caribbean coral reefs. Conservation Letters 11:1-9. DOI: 10.1111/conl.12571.

Sutherland KP, Porter JW, Turner JW, Thomas BJ, Looney EE, Luna TP, Meyers MK, Futch JC, Lipp EK. 2010. Human sewage identified as likely source of white pox disease of the threatened Caribbean elkhorn coral, Acropora palmata. Environmental Microbiology. DOI: 10.1111/j.1462-2920.2010.02152.x.

van Tussenbroek BI, Hernández Arana HA, Rodríguez-Martínez RE, Espinoza-Avalos J, Canizales-Flores HM, González-Godoy CE, Barba-Santos MG, Vega-Zepeda A, ColladoVides L. 2017. Severe impacts of brown tides caused by Sargassum spp. on near-shore Caribbean seagrass communities. Marine Pollution Bulletin 122:272-281. DOI: 10.1016/j.marpolbul.2017.06.057.

van Woesik R, McCaffrey KR. 2017. Repeated Thermal Stress, Shading, and Directional Selection in the Florida Reef Tract. Frontiers in Marine Science. DOI: 10.3389/fmars.2017.00182.

Vega Thurber RL, Burkepile DE, Fuchs C, Shantz AA, Mcminds R, Zaneveld JR. 2014. Chronic nutrient enrichment increases prevalence and severity of coral disease and bleaching. Global Change Biology. DOI: 10.1111/gcb.12450.

Walton CJ, Hayes NK, Gilliam DS. 2018. Impacts of a Regional, Multi-Year, Multi-Species Coral Disease Outbreak in Southeast Florida. Frontiers in Marine Science 5. DOI: 10.3389/fmars.2018.00323.

Weil E. 2004. Coral Reef Diseases in the Wider Caribbean. In: Coral Health and Disease. DOI: 10.1007/978-3-662-06414-6_2.

\section{Figure legends}

Figure 1. Susceptible species affected by Stony Coral Tissue Loss Disease during the outbreak. A) Two colonies of Pseudodiploria strigosa observed the 3rd of July, 2018 at a fore-reef reef site in Puerto Morelos, Mexico. One colony (front) shows the classic symptoms of the Stony Coral Tissue Loss Disease, while the other one died shortly before the photo was taken (recent and transient mortality). A Foureye butterflyfish (Chaetodon capistratus) is feeding on the edge of the lesion on the colony at the front. B) Diseased colony of Montastraea cavernosa in direct 
527 contact with an apparently healthy colony of the same species in Cozumel observed in Cozumel

528 the 3rd of July, 2019. The close-up shows the touching-boundaries between the two colonies.

529 Photo credits: Lorenzo Álvarez-Filip.

530

531 Figure 2. Prevalence of the Stony Coral Tissue Loss Disease for the 11 most susceptible species 532 across 82 reef sites in the Mexican Caribbean ( $\mathrm{n}=$ number of colonies). For this figure, we

533 include coral colonies with total mortality but for which death could be attributable to the

534 SCTLD (exposed bright white skeletons; see Fig. 1).

535

536

Figure 3. Prevalence of the Stony Coral Tissue Loss Disease in the Mexican Caribbean. Dots

537 represent the location of the 82 surveyed reefs and the colours represent the SCTLD prevalence

538 for the 11 most afflicted species (see methods and Fig. 2). Data on this figure was collected by

539 the Healthy Reefs Initiative, the Comisión Nacional de Áreas Naturales Protegidas (Mexican

540 Commission for Protected Areas; CONANP) and the Biodiversity and Reef Conservation

541 Laboratory, UNAM. Please note that reef sites were surveyed at different times (between July

5422018 and April 2019).

543

544 Figure 4. Disease prevalence of the 11 most susceptible species to the Stony Coral Tissue Loss

545 Disease (STCLD) from 2005/2006 to 2018/2019 in the Mexican Caribbean. From 2009 to 2014

546 black-band disease was the most abundant coral disease and was mainly recorded in Siderastrea 547 siderea in Cozumel.

548

549 Figure 5. Proportion of healthy, afflicted and dead colonies of the highly susceptible species in 550 2016/2017, before the onset of the Stony Coral Tissue Loss Disease Outbreak (SCTLD) in the 551 Mexican Caribbean, and in 2018/2019 when the SCTLD was spread across many sites in the 552 region.

553

554 Figure 6. Coral community composition for the study sites before and after the disease. Non555 metric multi-dimensional scaling (nMDS) analysis displaying degree of similarity of the 556 community composition across 14 sites in the Mexican Caribbean for the coral cover by species. 557 The blue color represent the sites before the disease (2016-2017) and the grey color represent the 558 sites after the disease (2018-2019). The circles represent the back-reef sites and the triangles the 559 fore-reef sites. Dotted lines: convex hull total area (TA). Solid lines: standard ellipse area 560 corrected for small sample sizes (SEAc). 


\section{Figure 1}

Susceptible species affected by Stony Coral Tissue Loss Disease during the outbreak

A) Two colonies of Pseudodiploria strigosa observed the 3rd of July, 2018 at a fore-reef reef site in Puerto Morelos, Mexico. One colony (front) shows the classic symptoms of the Stony Coral Tissue Loss Disease, while the other one died shortly before the photo was taken (recent and transient mortality). A Foureye butterflyfish (Chaetodon capistratus) is feeding on the edge of the lesion on the colony at the front. B) Diseased colony ofMontastraea cavernosain direct contact with an apparently healthy colony of the same species in Cozumel observed in Cozumel the 3rd of July, 2019. The close-up shows the touching-boundaries between the two colonies. Photo credits: Lorenzo Álvarez-Filip. 
(A)

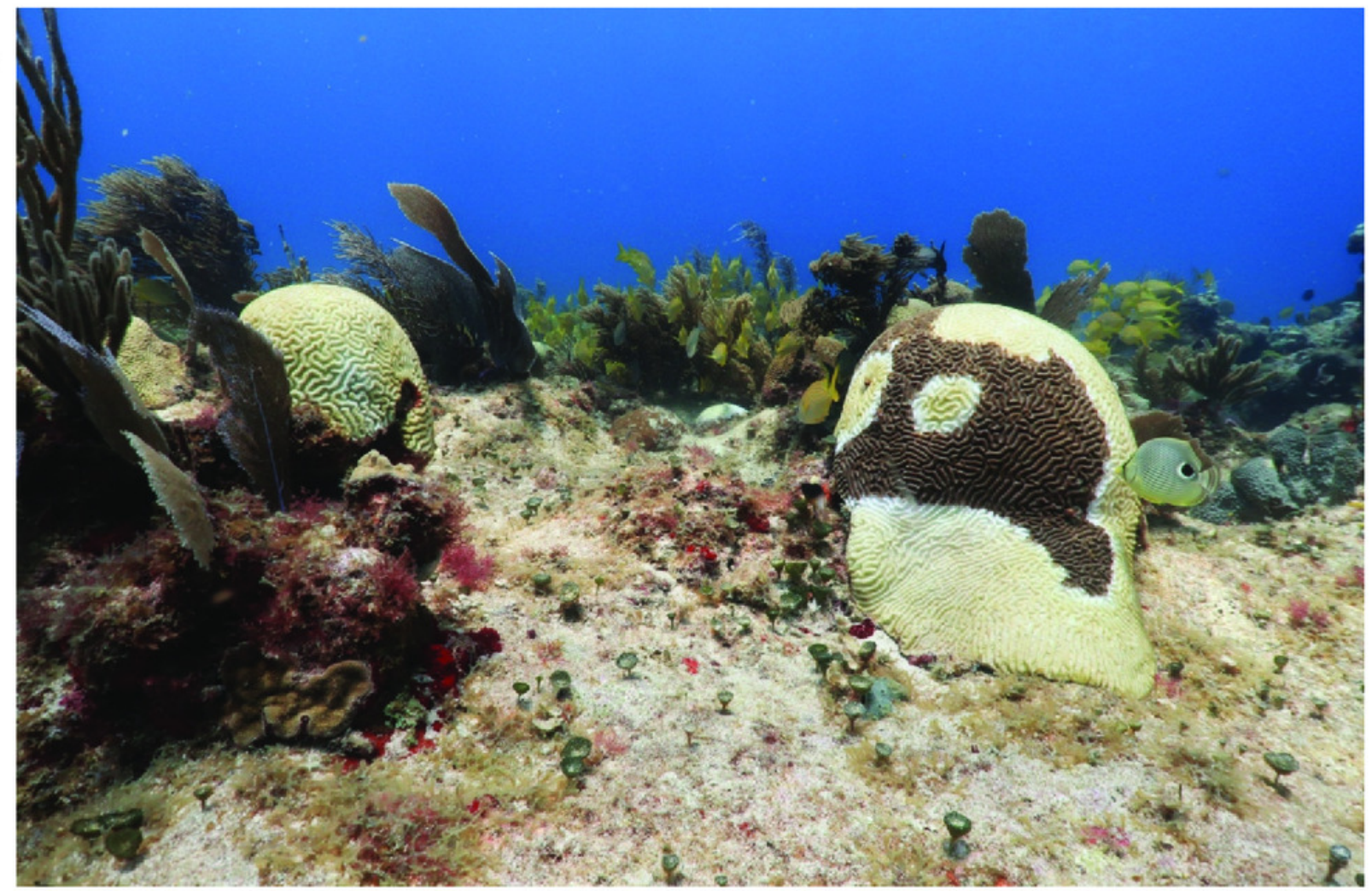

(B)

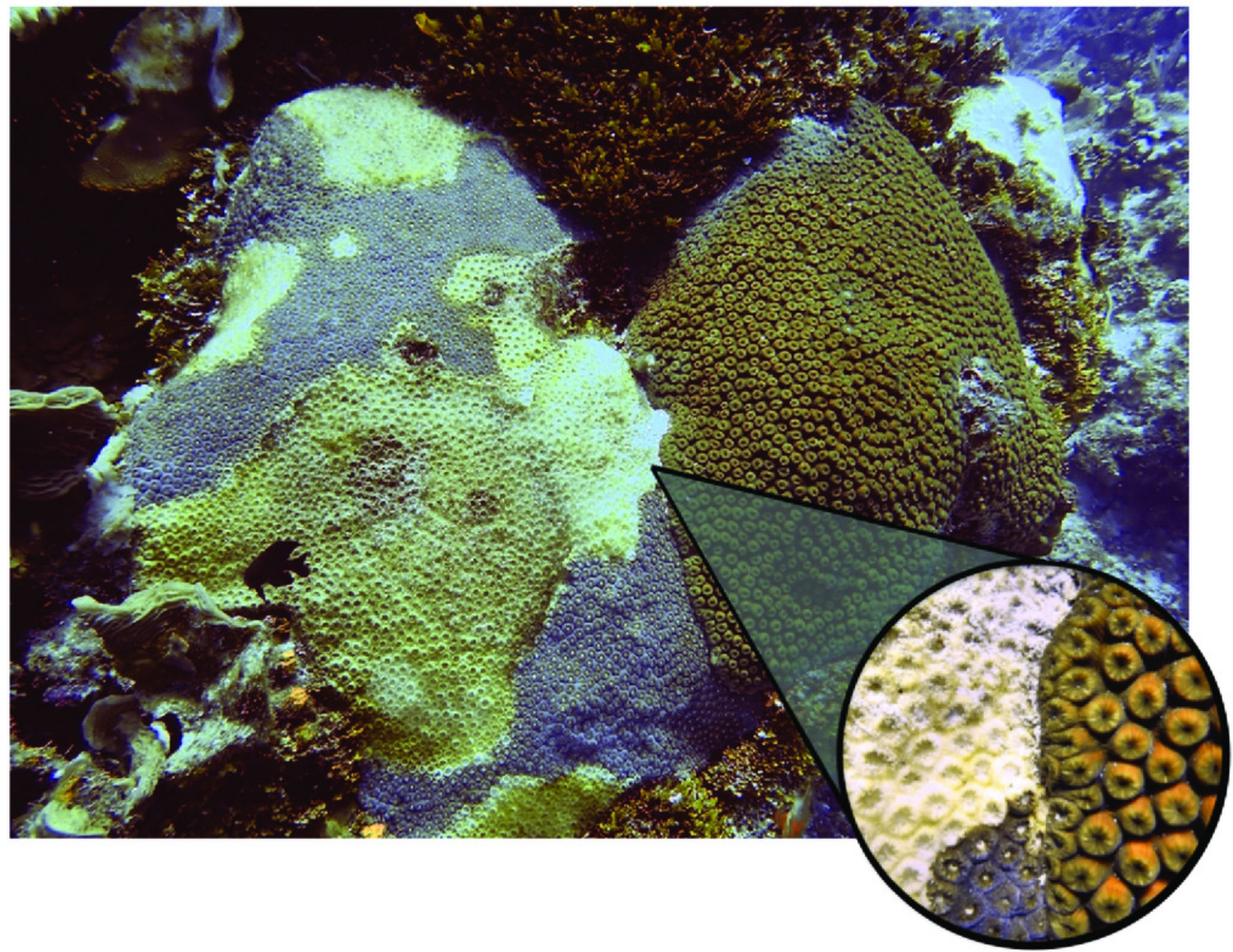




\section{Figure 2}

Prevalence of the Stony Coral Tissue Loss Disease for the 11 most susceptible species across 82 reef sites in the Mexican Caribbean ( $n=$ number of colonies).

For this figure, we include coral colonies with total mortality but for which death could be attributable to the SCTLD (exposed bright white skeletons; see Fig. 1).

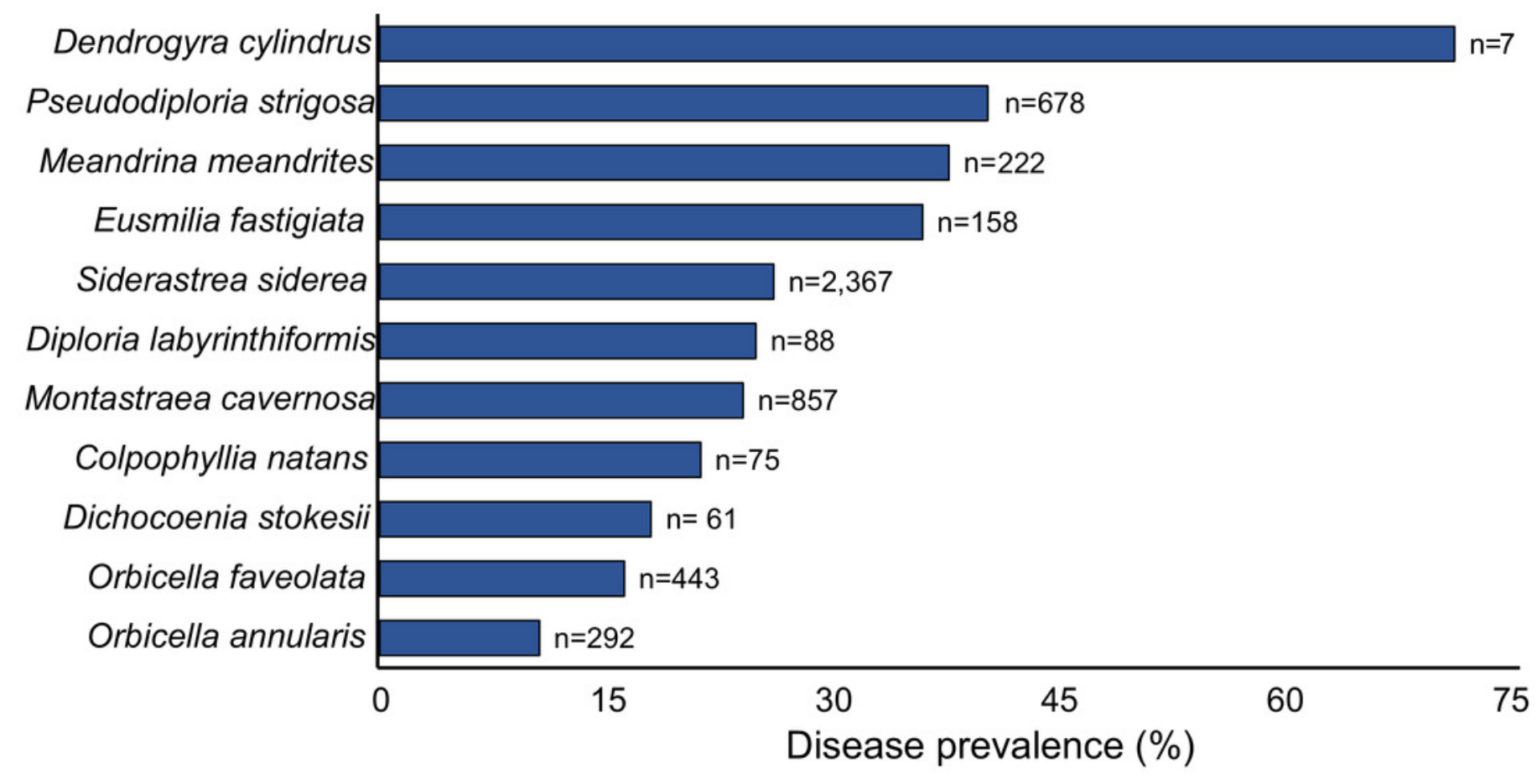




\section{Figure 3}

Prevalence of the Stony Coral Tissue Loss Disease in the Mexican Caribbean.

Dots represent the location of the 82 surveyed reefs and the colours represent the SCTLD prevalence for the 11 most afflicted species (see methods and Fig. 2). Data on this figure was collected by the Healthy Reefs Initiative, the Comisión Nacional de Áreas Naturales Protegidas (Mexican Commission for Protected Areas; CONANP) and the Biodiversity and Reef Conservation Laboratory, UNAM. Please note that reef sites were surveyed at different times (between July 2018 and April 2019). 


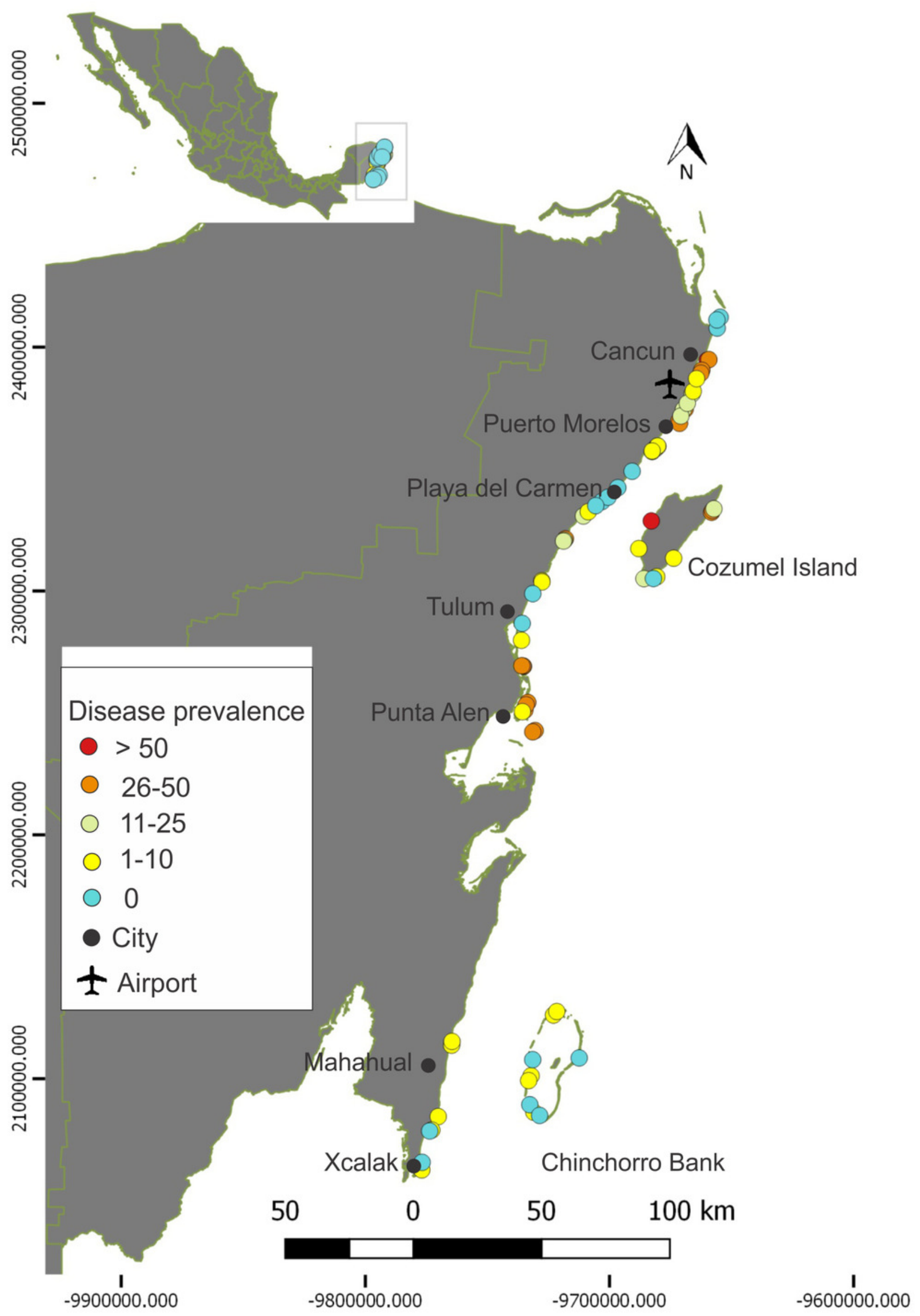


Figure 4

Disease prevalence of the 11 most susceptible species to the Stony Coral Tissue Loss Disease (STCLD) from 2005/2006 to 2018/2019 in the Mexican Caribbean.

From 2009 to 2014 black-band disease was the most abundant coral disease and was mainly recorded in Siderastrea siderea in Cozumel.

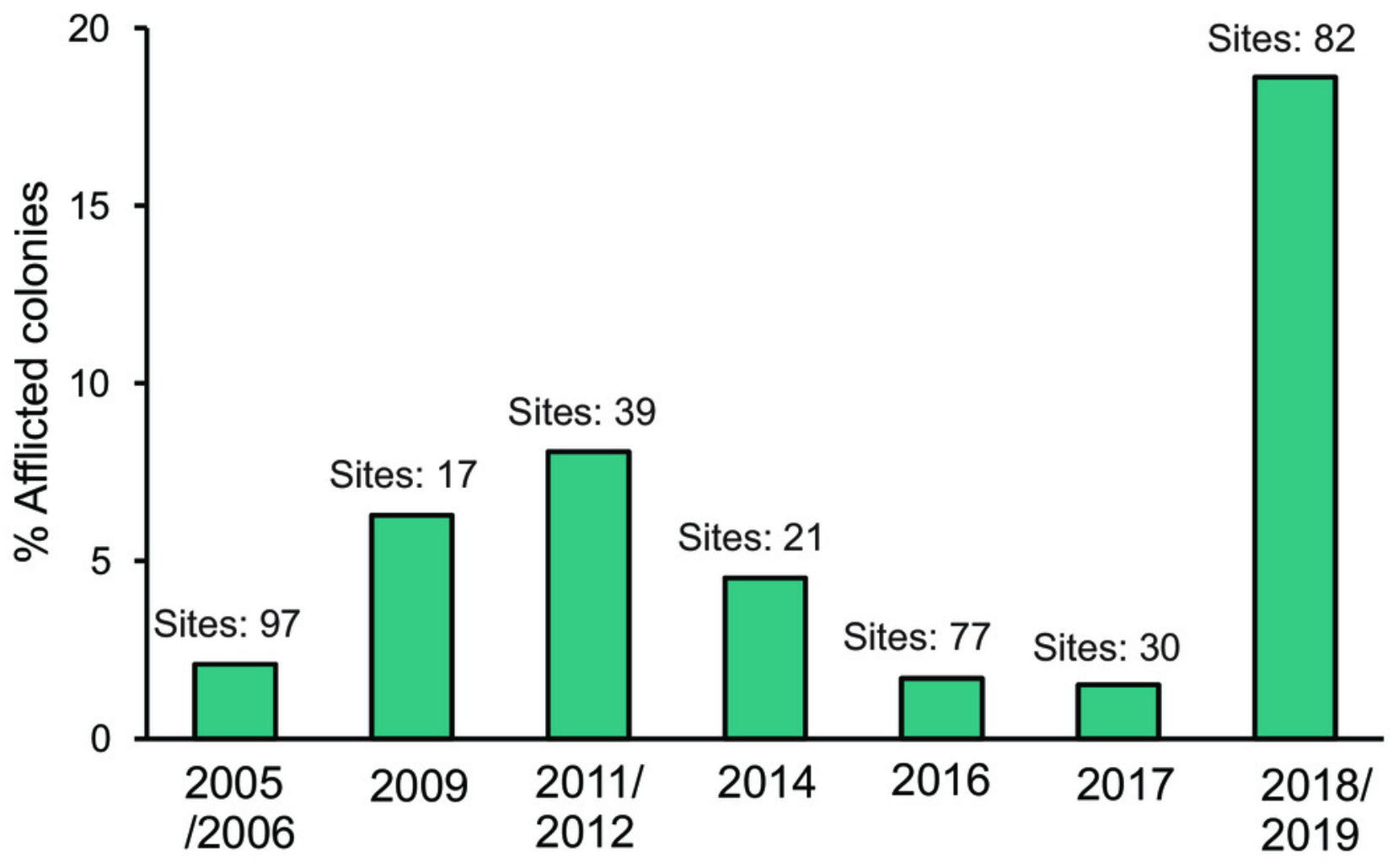




\section{Figure 5}

Proportion of healthy, afflicted and dead colonies of the highly susceptible species in 2016/2017, before the onset of the Stony Coral Tissue Loss Disease Outbreak (SCTLD) in the Mexican Caribbean, and in 2018/2019 when the SCTLD was spread across many si

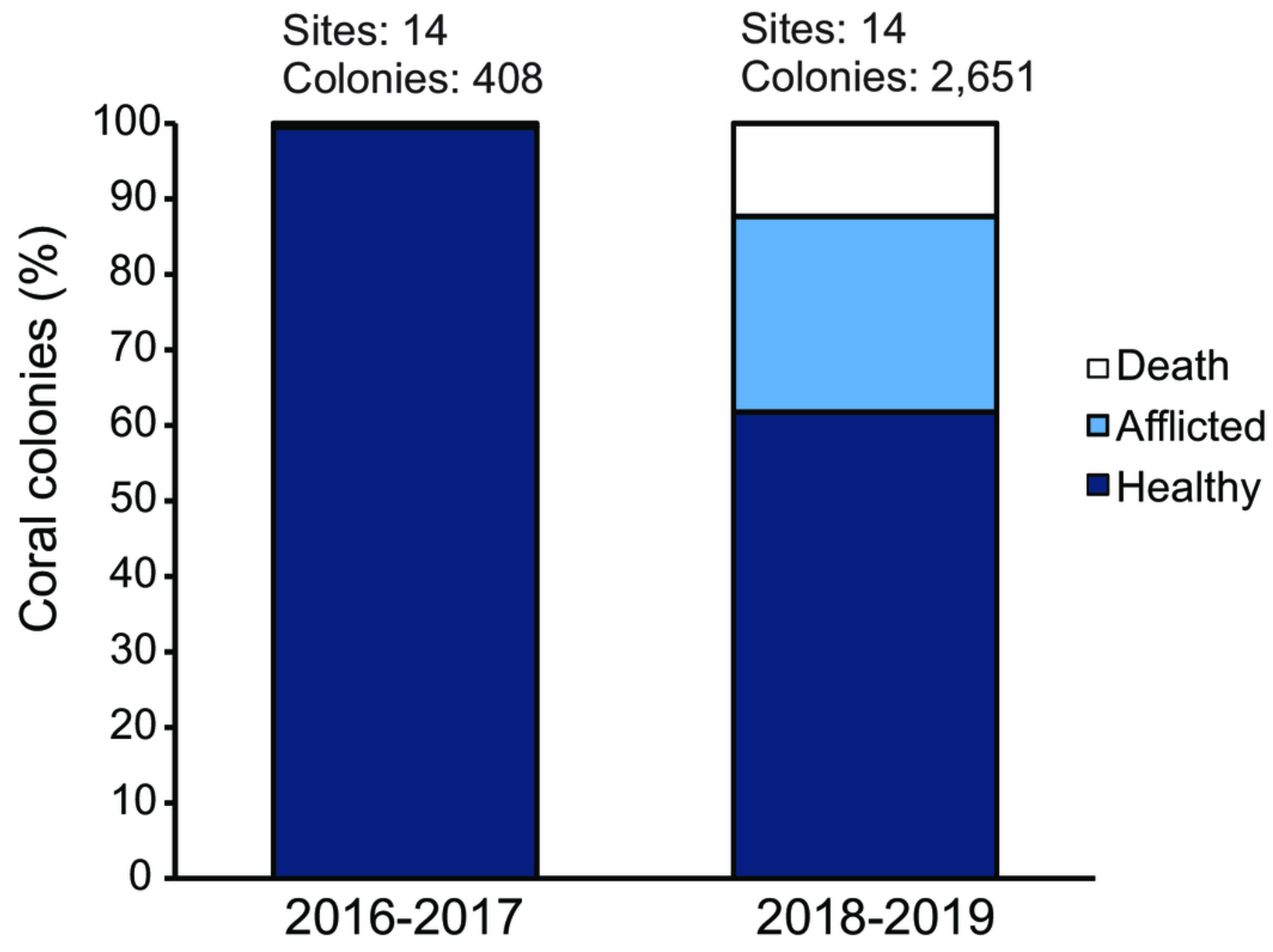


Figure 6

Coral community composition for the study sites before and after the disease.

Non-metric multi-dimensional scaling (nMDS) analysis displaying degree of similarity of the community composition across 14 sites in the Mexican Caribbean for the coral cover by species. The blue color represent the sites before the disease (2016-2017) and the grey color represent the sites after the disease (2018-2019). The circles represent the back-reef sites and the triangles the fore-reef sites. Dotted lines: convex hull total area (TA). Solid lines: standard ellipse area corrected for small sample sizes (SEAC).

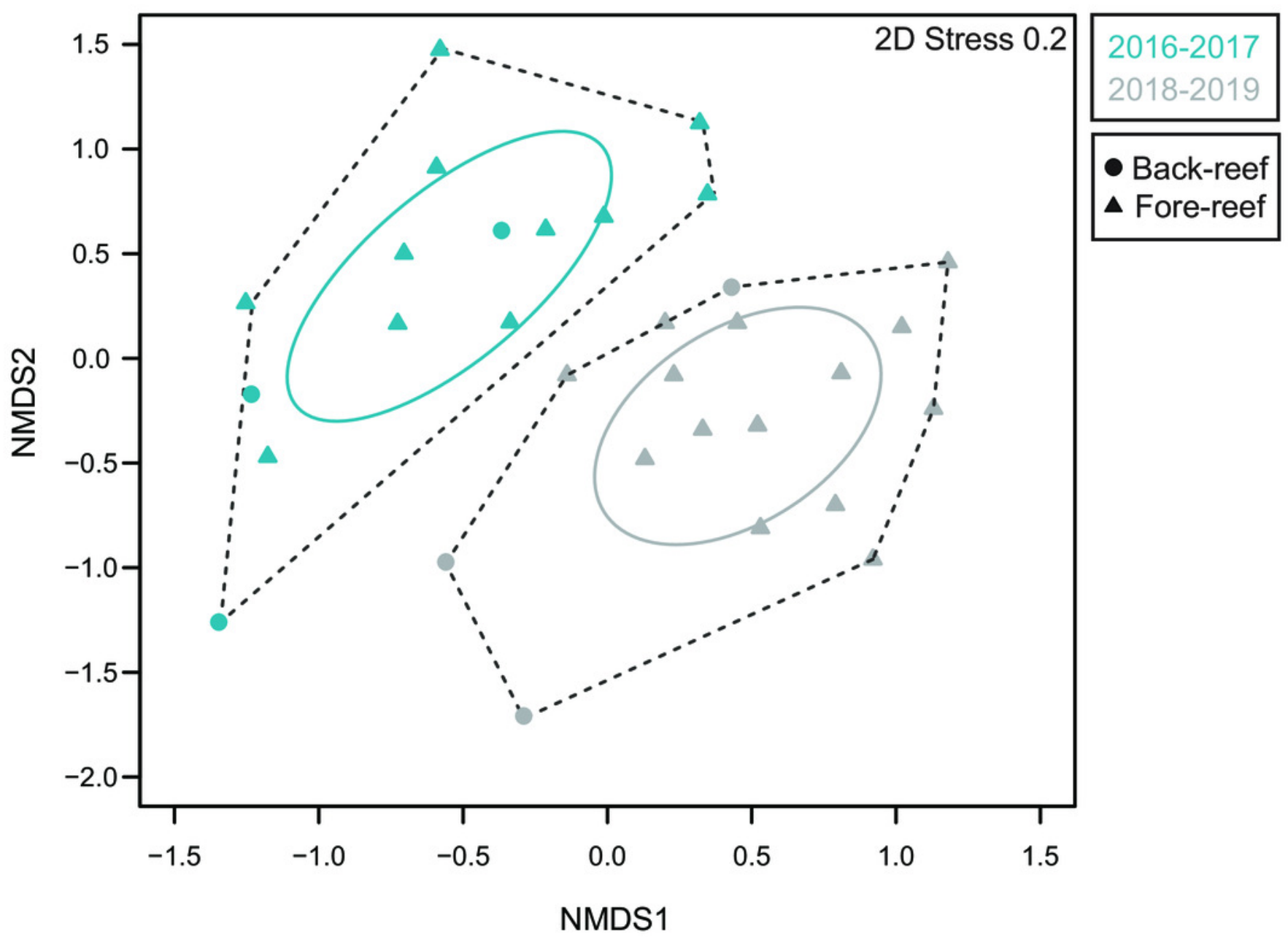

